\title{
Comparing Police and Public Perceptions of a Routine Traffic Encounter
}

Lyndel Bates PhD (corresponding author)

School of Criminology and Criminal Justice and the Key Centre for Ethics, Law, Justice and Governance, Griffith University

l.bates@griffith.edu.au

176 Messines Ridge Road

Mt Gravatt, Queensland, 4122, Australia

Phone: 61737351429

Fax: 61737355608

Emma Antrobus PhD

Institute for Social Science Research, The University of Queensland

e.antrobus@uq.edu.au

Sarah Bennett PhD

Institute for Social Science Research, The University of Queensland sarah.bennett@uq.edu.au

\author{
Assistant Commissioner Peter Martin PhD \\ Queensland Police Service \\ Martin.PeterJ@police.qld.gov.au
}

Submitted to Police Quarterly on 12 September 2014

Revised version submitted to Police Quarterly on 13 February 2015 
Keywords: Procedural Justice, Trust, Cooperation, Queensland Community Engagement Trial (QCET)

\section{*Acknowledgements}

The research reported in this article was funded, in its entirety, by the Australian Research Council (ARC) Centre of Excellence in Policing and Security (CEPS). The authors thank the team of researchers from The University of Queensland (Institute for Social Science Research) and Griffith University who participated in a variety of ways to bring this trial to fruition. In particular, this paper acknowledges Professor Lorraine Mazerolle as Chief Investigator. The partnership between the research team and the Queensland Police Service is particularly acknowledged. The views expressed in this material are those of the authors and are not those of the Queensland Police Service. The responsibility for any errors of omission or commission remains with the authors. The Queensland Police Service expressly disclaims any liability for any damage resulting from the use of the material contained in this publication and will not be responsible for any loss, howsoever arising, from use or reliance on this material.

\section{Biographical sketches}

Dr Lyndel Bates is a Lecturer in the School of Criminology and Criminal Justice and a member of the Key Centre for Ethics, Law, Justice and Governance at Griffith University. Lyndel has a strong background in both criminology and traffic psychology and her PhD examined young driver experiences of, and compliance with, graduated driver licensing systems. Her current research interests include policing, the intersection of health and criminology, criminological theory and the translation of research into policy. 
Dr Emma Antrobus is a research fellow at the Institute for Social Science Research (ISSR). Emma has a background in social psychology and has interests in the legitimacy of social agencies, crime prevention and child protection. Emma's recent research focuses on randomized controlled trials examining the impact of police behaviour and legitimacy, interventions for young people at risk, and court processes and decision-making involving child witnesses.

Dr Sarah Bennett is a research fellow at the Institute for Social Science Research (ISSR). Sarah is an experimental criminologist with experience in running multisite randomized controlled trials with police in Australia and the U.K. and was the project leader for the Queensland Community Engagement Trial. Sarah’s research interests include legitimacy and policing, restorative justice, pathways to preventing offending, and the impact of crime on victims. Sarah is a fellow of the Academy of Experimental Criminology (AEC) and recipient of the distinguished AEC Young Scholar Award and Nigel Walker Prize (Cambridge University).

Assistant Commissioner Peter Martin has a Ph.D. having studied extensively in the field of police intervention to reduce alcohol-related harm in and around licensed premises. His interest are, and he has published widely on, subjects relating to policing, police-related research, alcohol-related harm and police-researcher relationships and translational criminology. Together with Professor Lorraine Mazerolle, Peter was involved with the inception of the Queensland Community Engagement Trial (QCET) which was facilitated in Queensland, Australia. Peter has been awarded the Australian Police Medal and other distinguished awards in policing. He is also an inductee in the Evidence Based Policing Hall of Fame, George Mason University, USA. 


\section{Comparing Police and Public Perceptions of a Routine Traffic Encounter}

Police perceptions of procedural justice are less well understood than citizen perceptions. Our paper compares the views of police officers and citizens of a routine Australian policing encounter, the Random Breath Test. We examine perceptions of two versions of their encounter: a business as usual and a more explicitly procedurally just interaction. Our results indicate that the procedurally just version affected the views of police officers, but not drivers, regarding the reasons for conducting Random Breath Tests. It also appears that police officers believe that the encounter has a greater impact on drivers' views than the drivers report themselves. This study has important implications for policing as it demonstrates that incorporating procedural justice within police-citizen interactions affects police officers as well as the citizens. It also highlights the importance of using external (e.g. larger community) measures, in addition to internal measures (e.g. within police organization), when assessing the effectiveness of police organizations to ensure a more complete picture. 


\section{Comparing Police and Public Perceptions of a Routine Traffic Encounter: What can we learn from QCET?}

\section{Introduction}

The emergence of community policing over the past 30 years as a dominant influence in policing practice has led to a greater focus on the way that police act and the public's perceptions of their actions. Exploring how both police and citizens perceive the same interactions allows for greater understanding of how police and citizen views align, and how discrepancies in views may influence policing practice. There has been an increasing amount of research undertaken internationally that examines citizens' attitudes towards police (Brandl, Frank, Worden, \& Bynum, 1994; Brown \& Benedict, 2002; O'Connor, 2008; Vogel, 2011; Waddington, Williams, Wright, \& Newburn, 2015). This body of research considers a wide variety of contributing factors including age (Lai \& Zhao, 2010; Reisig \& Correia, 1997; Sargeant \& Bond, in press), gender (Vogel, 2011), race (Cheurprakobkit, 2000;

Oliveira \& Murphy, in press; Wu, Sun, \& Triplett, 2009), education (Chow, 2011; Vogel, 2011), socio-economic status (Brown \& Benedict, 2002; Wu et al., 2009), neighbourhood context (Bridenball \& Jesilow, 2008; Vogel, 2011), the impact of media coverage on citizens' attitudes (Chermak, McGarrell, \& Gruenewald, 2006), previous contact with police (Bridenball \& Jesilow, 2008; Chow, 2011) and whether a person was previously a victim of crime (Aviv, 2014; Chow, 2010; Lai \& Zhao, 2010).

Considerably less is known about how the police perceive their own interactions with the public as compared to how the public perceive the police during a similar encounter. Concepts such as procedural justice are nearly always examined from the perspective of citizens. This is understandable given that it is the citizens' perceptions that will influence perceptions of legitimacy, and in turn, willingness to cooperate with the police (JonathanZamir, Mastrofski, \& Moyal, in press; Tankebe, 2009; Tyler \& Huo, 2002). However, 
without an understanding of police officers' perceptions, we are left with a single-sided view. There exists some research internationally which examines police attitudes and perceptions and their impact on various aspects of police behavior, however, this research tends to focus on factors that influence policing behaviors (e.g. A. Jackson \& Wade, 2005; Wells \& Schafer, 2006), or differences in police views based on factors such as gender (Kennedy \& Homant, 1985). There is even less research that compares the perceptions of police and citizens on the same presenting issues or encounter. In this paper, we utilise the Queensland Community Engagement Trial (QCET) to explore both police and citizen views towards police in relation to a routine Australian encounter with police - the random breath test (RBT). An RBT can be either stationary (such as a checkpoint set up by the side of the road) or mobile. They involve police officers randomly selecting drivers and using a hand held device that drivers breathe into in order to assess their blood alcohol level (Ferris et al., 2013). Our findings provide police with a greater understanding of the practical implications of using procedural justice in encounters with citizens. This paper reviews the literature in the fields of police-citizen encounters, procedural justice and legitimacy and random breath testing before describing the experimental method. The two surveys, one for the drivers and the second for the police, are described. We then discuss the results and the implications of this study.

\section{Perceptions of Police-Citizen Encounter}

Perceptions and attitudes drive the way that people behave (e.g. Ajzen \& Fishbein, 1977). Citizens' perceptions of police guide not only the way that citizens feel about the police, but also the way that they act when encountering police. In the same way, the perceptions that police have about the general public can shape the way that they manage encounters with citizens (J. Jackson, Bradford, Kuha, \& Hough, in press). How the police are perceived by the public is important because it provides a measure of the value and performance of policing 
services (Adams, Rohe, \& Arcury, 2005; Frank, Smith, \& Novak, 2005; Vogel, 2011).

Citizens' attitudes provide information about their perceptions of police performance (Frank et al., 2005). Additionally, information about citizens’ attitudes may help to hold police accountable to the general public, which may enhance perceptions of police legitimacy (Moore, 1992). Citizen attitudes towards police are relatively easy to measure and the information can be collected by survey (Frank et al., 2005).

The views of citizens are particularly important in the context of community policing (Frank et al., 2005). Community policing involves engaging citizens as equal partners in the process of managing crime and disorder (Morabito, 2010). It aims to increase trust between the two groups and enhance citizen perceptions (Frank et al., 2005). Gaining an understanding of the interactions that occur between police and citizens, and subsequent citizen perceptions, is therefore vital as many of the strategies and approaches used by police assume that both groups are acting together to address common goals (Liederbach, Fritsch, Carter, \& Bannister, 2008).

The police and public may have different views of the same policing event, although this is rarely investigated in a rigorous manner. For example, surveys are rarely administered to both police and citizens at the same time (Liederbach et al., 2008). However, Lopez and Lukinbeal (2010) conducted in-depth interviews with 38 citizens and 5 police officers surrounding their views on crime areas in Phoenix. The citizens focussed on identifying safe areas, while the police tended to focus on areas that they considered dangerous.

Further, a study examined police and citizen perceptions of racially biased policing in Virginian police departments. The researchers identified that police and citizens had opposing views on bias-based policing issues. For instance, their results showed that 42.8 per cent of citizens felt that bias-based policing was present in Virginian police departments, while 21 
per cent of police officers reported that bias-based policing was presently practised within their organization (Ioimo, Becton, Meadows, Tears, \& Charles, 2009).

Thus, there is very limited research regarding the views of police and citizens of the same event and no research comparing the views of these groups for a procedurally just interaction. This is despite, as shown below, evidence suggesting many benefits of including procedural justice in interactions between police and citizens.

\section{Procedural Justice and Legitimacy}

The legitimacy of authorities, such as the police, is paramount for ensuring their ability to work effectively. International research suggests that legitimacy is important because it promotes voluntary respect and cooperation from citizens (e.g. Hinds \& Murphy, 2007; Sunshine \& Tyler, 2003; Tyler, 2003; van der Toorn, Tyler, \& Jost, 2011). Police need public support and cooperation in order to maintain order in the community, and this support and cooperation is linked to public perceptions about police legitimacy (Tyler, 2004). Contact with police can alter one's attitudes towards the police. However, it is the nature of this contact, rather than the contact in and of itself, that impacts citizen's perceptions (Cordner \& Jones, 1995; Tyler, 2003). A recent surge of interest in police legitimacy has focused on the premise that procedural justice, or the quality of treatment, is the mechanism linking the effects of police-citizen contact to perceptions of the police, primarily perceptions of police legitimacy (Hinds \& Murphy, 2007; Sunshine \& Tyler, 2003; Tyler, 2003).

Research has consistently shown that people are more likely to view the police as legitimate if the police act in a procedurally fair manner. That is, people need to feel that they are treated in an unbiased, respectful manner, that they are able to have a voice in decision making, and that the police act with trustworthy motives (Goodman-Delahunty, 2010; Lind \& Tyler, 1988; Murphy, 2009; Murphy, Mazerolle, \& Bennett, 2014; Sargeant, Murphy, Davis, 
\& Mazerolle, 2012). Longitudinal research conducted in the United States of America has also shown the importance of police implementing the principles of procedural justice in their interactions with citizens (Gau, 2010). Procedural justice, therefore, is considered key for ensuring that police are seen as legitimate (Gau, Corsaro, Stewart, \& Brunson, 2012), and for receiving the public's cooperation and compliance.

In addition to the role procedural justice plays in ensuring that police are seen as legitimate, distributive justice is also important. In comparison to procedural justice, distributive justice focuses on the fairness of the outcome of the interaction (Tyler \& Wakslak, 2004). Research suggests that distributive justice and police performance are important predictors of police legitimacy and public cooperation with police activities. However, researchers have found procedural justice to be the strongest influence when compared with distributive justice and police performance (Hinds \& Murphy, 2007; Murphy, Hinds, \& Fleming, 2008). It is therefore important for police agencies to consider how their officers interact with citizens rather than solely focussing on the outcomes.

Whilst there are many types of situations where citizens have formal encounters with police, the most common type of encounters are the result of road policing in a number of countries including Australia (Roberts \& Indermaur, 2009), the United Kingdom (Allen, Edmonds, Patterson, \& Smith, 2006; Skogan, 1990) and the United States of America (Hoover, Dowling, \& Fenske, 1998). In Australia, Random Breath Testing (RBT) was introduced into most states by the early 1980s. Queensland was one of the last states to adopt RBT as a routine road policing activity in 1988 (Homel, 1989). Of Australians who report contact with police in the past 12 months, approximately 57\% indicated that it was during an RBT encounter (Roberts \& Indermaur, 2009) making it one of the most frequent points of contact between members of the public (either as drivers or bystanders) and police officers. 
Given the frequency of contact between police and the public, the perceptions that individuals develop of police as a result of these interactions is therefore important.

\section{The Philosophy of Random Breath Testing (RBT)}

A significant component of road policing is focused on combating driving while intoxicated. ${ }^{1}$ Alcohol related crashes are a significant problem as they result in considerable deaths, injuries and property damage. RBT is a key countermeasure used to reduce driving while intoxicated in Queensland and in all other Australian jurisdictions (Bates, Soole, \& Watson, 2012; Watson \& Freeman, 2007). The RBT process enables police officers to stop any driver at any time in order to administer a breath test to assess if the driver is under the influence of alcohol (Voas \& Fell, 2013). The vast majority of the drivers who interact with police have not committed a driving under the influence offence. Evaluations of RBT programs suggest that it is effective in reducing fatalities and injuries caused by driving while intoxicated (see Peek-Asa, 1999).

Deterrence theory is frequently used to explain the effects of RBT as an enforcement method (Bates et al., 2012; Davey \& Freeman, 2011; Freeman \& Watson, 2006). There are two types of deterrence concepts that target different groups: general deterrence and specific deterrence (Nagin, 2013). General deterrence occurs when the population as a whole avoids committing an offence because they perceive there is certainty of being detected if they commit an offence, and perceive severity and swiftness of a punishment once they are caught (Bates et al., 2012). In contrast, specific deterrence occurs when the behavior of an individual is altered as a result of being caught committing an offence. They are deterred from committing future offences as a result of their detection and punishment (Ferris et al., 2013).

\footnotetext{
${ }^{1}$ We acknowledge that various terminology such as driving under the influence, driving while intoxicated, drink driving and drunk driving are used in different jurisdictions.
} 
The Queensland Police Service (QPS) conducts extensive numbers of RBTs each year with the current ratio set at one RBT for every registered driver within the state (Ferris et al., 2013; Mazerolle, Bennett, Antrobus, \& Eggins, 2012; Watson \& Freeman, 2007). ${ }^{2}$ In Queensland, nearly one in four policing incidents involved vehicles and traffic. Of these, 41 per cent involved alcohol (Palk, Davey, \& Freeman, 2007a, 2007b). Research suggests that incidents that involve alcohol and traffic comprise a large component of the work undertaken by police officers (Myrstol, 2012; Palk et al., 2007a, 2007b).

Despite the significant amounts of time spent by police officers on policing alcoholrelated traffic incidents, there is limited research regarding the views of police and drivers for RBTs and there are no studies that directly compare the view of these two groups. However, research by Watson and Freeman (2007) indicates that there is public support for RBTs and that most people believe that driving while intoxicated is a serious offence. Watson and Freeman (2007) surveyed 780 motorists from a random sample of residents in Queensland and found that three-quarters of the sample reported that they had seen a RBT being conducted by police within the past six months, and 41 per cent of the sample reported that they had been breath tested by police within the past six months indicating the significance of the RBT program in deterring potential drunk drivers.

The use of RBTs requires police to undertake a task that is designed to reduce the number of arrests that they make for a particular offence (driving while intoxicated). When the RBT program works effectively, it is designed to operate in a general deterrent manner and discourage drivers from drinking while over the legal BAC limit rather than focussing on apprehending those who are driving under the influence of alcohol (Homel, 1993). However, police officer managers/supervisors show some confusion over the deterrence role of RBT operations (Hart, Watson, \& Tay, 2003). A Queensland study that involved 22 unstructured

\footnotetext{
${ }^{2}$ A description of the process for conducting RBTs within Queensland is available elsewhere (Mazerolle et al., 2012).
} 
interviews with 30 police officers found that police officers in managerial/supervisory roles were aware of public support for RBTs. The police officers interviewed indicated that the RBT was an important activity for the police to conduct in order to both deter and detect drunk drivers. While some managers believed that the aim of the RBT program was to generally deter people from driving while intoxicated, others thought that it was to specifically detect drunk drivers. Some participants indicated that the detection of drunk drivers (e.g. specific deterrent) should be the primary aim of the RBT program (Hart et al., 2003). Despite the confusion over the role of RBTs, police officers - both managers and operational police - show a strong commitment to the RBT program and are aware of the strong community support for the RBT program (Hart et al., 2003). Police officers also raised the issue of quality versus quantity in relation to RBTs. They suggested that the imposition of a quota, such as the one implied in Queensland with one RBT conducted for every licensed driver within the state, did not allow a high quality RBT interaction (Hart et al., 2003).

\section{The Present Study}

The goal of the present study is to compare and contrast police and public perceptions of a routine enforcement encounter in Australia. Using data from the Queensland Community Engagement Trial (QCET), we explore driver and police views of RBT interactions. QCET was a criminological experiment that examined the impact of a procedurally just policecitizen encounter on perceptions of police. The specific police-citizen encounter selected was a RBT. Previous papers have reported on various aspects of QCET including the main findings (Mazerolle et al., 2012), citizen perceptions regarding the specific interaction, perceptions of the police more broadly (Mazerolle, Bennett, Antrobus, \& Tyler, 2013), the promotion of trust in police (Murphy et al., 2014), the impact of encounter length (Mazerolle et al., in press) and interactions with social identity (Sargeant, Antrobus, Murphy, Bennett, \& 
Mazerolle, in press). This paper adds to our understanding of police-citizen interactions by considering and comparing the view of both police and citizens of a standard and procedurally just RBT interaction.

\section{Method}

The Queensland Police Service (QPS) identified RBTs as a routine and consistent police-citizen encounter which could be tested using a randomized controlled trial (RCT). Mid-sized RBT operations were targeted within the Metro South Region of Brisbane as the operations are supervised, regularly involve between five to ten officers, more likely to reach drivers living in the region and average around 500 breath tests during a single police shift. At the time of the trial, Metro South averaged nine mid-sized operations per month. Between December 2009 and July 2010, 60 RBT operations were randomly assigned to either the control condition or the experimental condition.

\section{Control Condition}

The RBTs in the control condition were conducted as per standard operating procedure except that at the end of the breath test, officers provided drivers with a sealed envelope and asked drivers to complete the survey at a later time and return ${ }^{3}$ the surveys to the University of Queensland using the postage paid envelope enclosed. Police handed 400 surveys to drivers at each of the 30 control operations. The 'standard' operation involved temporary RBT sites set up on roads with sufficient traffic and visible police signage (e.g., flashing lights and cones). One officer stood at the front of the RBT site and directed five to ten drivers at a time to park in a designated area in front of officers waiting to conduct the breath test. Officers instructed drivers to put down their windows and delivered a short mandated

\footnotetext{
${ }^{3}$ Surveys were voluntary and no personally identifying data was requested
} 
message about the requirement of drivers to comply with the RBT and then asked drivers to breathe into a calibrated breath testing device. Once complete, drivers who had a blood alcohol level under $.05^{4}$ were instructed to drive on. Drivers over the breath alcohol limit (or who had committed any other infringement) were taken to a processing area. RBTs in the control condition lasted on average for 25.51 seconds.

\section{Experimental Condition}

The 30 experimental operations expanded on the standard RBT procedure. Prior to the mandated message, police officers used a scripted dialogue which operationalized the four ingredients of procedural justice. Specifically, officers demonstrated neutrality and trustworthy motives when they explained to drivers that they had been pulled over at random and that the purpose of the RBT was to reduce the number of alcohol related crashes and fatalities. Officers stated the current number of deaths on Queensland roads and described how difficult it was to tell someone that their loved ones had been injured or killed in a road incident. Officers encouraged drivers to participate throughout the encounter by asking drivers if they had any questions. Police demonstrated dignity and respect when they thanked drivers for their time and attention and commented on something positive the drivers had done to keep their vehicle safe or comply with Queensland Road Rules ${ }^{5}$ (e.g. using correct child restraints). At the end of the breath test, RBT officers provided drivers with a sealed envelope which also had a community information bulletin attached. This community bulletin, prepared by the QPS, provided information about local police events and resources and listed safety strategies such as locking up valuables or locking doors/windows at night.

A card which listed the four elements of procedural justice and how they could be applied was given to each officer participating in the experimental operation. RBT officers were

\footnotetext{
${ }^{4}$ In Queensland, the alcohol limit is .05 grams per 100 milliliters of blood for full license holders

${ }^{5}$ Officially known as the Transport Operations (Road Use Management-Road Rules) Regulation 2009
} 
encouraged to use their own conversational style whilst ensuring that each of the elements was delivered during the encounter. The average length of police-driver encounters in the experimental condition was 99.11 seconds. Police handed out 300 surveys (with attached community bulletin) at each experimental RBT operation. Consistent with the control condition, if drivers had committed any infringement or were over the limit, officers still followed standard enforcement procedures after the survey had been provided.

\section{Driver survey}

Police distributed 20,985 surveys ${ }^{6}$ to drivers during the 60 RBT operations. Drivers returned 2,747 surveys which resulted in an overall response rate of 13\%. Drivers who had taken part in control operations (e.g. the standard RBT) had a slightly higher response rate (13.73\%) than drivers from the experimental condition (12.30\%). Analysis suggests that the substantive results of QCET are not affected by the low response rate with Antrobus et al (2014) (Antrobus, Elffers, White, \& Mazerolle, 2013) demonstrating the low probability for response bias impacting on previous findings from the QCET study (e.g., Mazerolle et al., 2012) ${ }^{7}$.Equivalency tests further confirmed that there were no significant differences between experimental and control conditions for age, gender or ancestry. Female and male respondents were almost equivalent (50.42\% female versus $49.58 \%$ male) and ranged from 17 to 90 years with a mean age of $47(S D=14.71)$.

The survey aimed to understand driver's perceptions of the purpose of RBTs, the quality of their encounter with police and their level of community engagement. Basic demographic data was also collected but nothing which could identify the driver, making it impossible to

\footnotetext{
${ }^{6}$ One experimental RBT operation was closed early because of extreme weather and the last 15 surveys were not distributed.

${ }^{7}$ Antrobus et al. (2014) examined the QCET data to explore the impact of non-responders differentially impacting the results in the control and experimental conditions, finding that the results were robust even under extreme conditions. Thus, even though only a small proportion of possible respondents returned their survey, the level of non-response did not bias the resulting significant difference between the experimental and control groups.
} 
follow up with people who did not return the survey. Procedural justice and legitimacy questions were drawn from the seminal work by Murphy, Murphy, and Mearns (2010) and Tyler and colleagues (e.g. Sunshine \& Tyler, 2003; Tyler, 2003, 2004; Tyler \& Fagan, 2008; Tyler \& Huo, 2002).

\section{Police Survey}

All officers who conducted RBTs in the experimental and control operations were asked to complete a survey at the end of the operation. Officers were asked to reflect on the purpose of RBTs, the quality of their interaction with drivers and whether encounters would change drivers' behavior (e.g., driving while intoxicated). To maintain anonymity officers provided only basic demographic data such as gender, year of birth and years served within the QPS. Officers who conducted QCET RBTs in multiple operations and/or conditions were asked to think about “today’s Random Breath Test (RBT) operation” when completing the survey. There were approximately 469 police officers ${ }^{8}$ involved in the trial across both conditions $($ Control $=249$; Experimental $=220)$. A total of 202 police surveys were returned over the 60 RBT operations (response rate $=43.07 \%$ ), 114 from officers delivering the experimental intervention (51.82\% response) and 88 (35.34\% response) from officers conducting control operations. $^{9}$

Officers were asked to indicate how many times they had previously taken part in a QCET RBT operation. Based on this item, 23.76\% of police respondents $(n=48)$ were responding for the first time, and these officers were evenly distributed in the control and

\footnotetext{
${ }^{8}$ The number of officers participating in each of the 60 RBTs operations was summed. This number does not take into account officers being involved in multiple operations. - i.e., a police officer attending 3 operations is counted 3 times. There is some missing data from our observations on the numbers of officers present, however, where the data was missing, the average number of officers for that district was imputed to allow for the estimation of total numbers.

${ }^{9}$ Police surveys were generally completed on the spot before packing up the RBT site in experimental operations. As control operations were much shorter, officers often continued conducting RBTs after QCET RBTs were completed. For continuing RBTs, researchers provided officers with a survey and asked them to return via a pre-paid envelope enclosed. The greater response in the experimental condition is statistically significant.
} 
experimental conditions ( $n=24$ in each group). A further $25.25 \%$ of officers $(n=51)$ did not answer this question, slightly more in the control group $(n=29 ; 32.95 \%)$ than the experimental ( $n=22 ; 19.30 \%)$. When they did report previous involvement in the QCET, the number of previous operations officers reported to have taken part in ranged from one to ten operations, with an average of almost three (2.95) operations per respondent. ${ }^{10}$

Overall, the average age of officers involved in the trial was 38.37 years $(S D=8.74)$, with equivalent ages in both the experimental and control operations (experimental: 37.73 year, $S D=8.75$; control: 39.33 years, $S D=8.78, t(116)=-0.99, p=.327)$. Eighty two percent of police respondents were male (57 missing gender) and the length of service with Queensland police ranged from 1 month to 35 years (average length of service $=11.41$ years, $\mathrm{SD}=10.15)$. Proportions of males and females across the conditions were consistent, $\chi^{2}(1, n$ $=145)=0.12, p=.825$, and average length of service did not differ for the experimental and control officers, $t(136)=-1.052, p=.295 .^{11}$

\section{Measures}

Both drivers and police were asked about their perceptions of how the police (or they themselves, in relation to police officers) acted during the RBT, in terms of how approachable and friendly, helpful, polite, professional, fair, and clear in explaining the RBT procedure (scale 1-5, 1=Strongly disagree to 5=Strongly agree). Responses on these items were combined (averaged) to form a scale of Police Behavior in the RBT (Cronbach's alpha

\footnotetext{
${ }^{10}$ It was possible for officers to answer multiple surveys due to being involved in multiple operations. Due to the de-identified nature of the survey it was not possible to cross check and link officers to their multiple surveys where this occurred. However, based on observation data of the operations, these figures appear to reflect the average numbers of operations per officers as observed. There were approximately 122 unique officers involved in the trial.

${ }^{11}$ Looking at first time officer respondents $(n=48)$ only, these results were fairly similar. Average age $=$ $36.49, S D=8.64$, average length of service $=9.87$ years, $S D=10.73$, percent males $=76.60 \%$.
} 
$=.928)$. Participants were asked six questions to assess their perceptions of trust in police officers (Scale 1-5; 1=Not important to 5=Very Important). These questions were:

- How important do you think it is for police to:

o Be accountable for their actions

o Keep the public informed

o Be open and honest when dealing with the public

o Treat people with respect

o Be interested in the well-being of ordinary Australians

o Share the goals of ordinary Australians

Responses on these items were combined (averaged) to form a trust norms scale

(Cronbach’s alpha $=.778)$.

The willingness to cooperate with police scale comprised four items (scale 1-5; 1=Very unlikely to 5=Very likely). Drivers were asked:

- How likely would you be to

o Call police to report a crime

o Willingly provide police with information about crime suspects

o Report dangerous or suspicious activities to police

o Willingly assist police if asked

Police officers were asked the same items but with a different question preamble ('In your experience over the last year, how likely do you think citizens are to...”). Responses on these items were combined (averaged) to form a Cooperation scale (Cronbach’s alpha = .833).

\section{Methodological Strengths}

A key strength of the method used in this paper is the randomized experimental approach which has been used in a very limited way within criminology (Farrington \& Welsh, 2005). However, the use of a randomized experimental design is the best way to ensure high levels of internal validity and thus support that alterations made to the treatment are related to effects (Farrington, 2003). Very few experiments have been conducted outside of the United States of America (Farrington \& Welsh, 2005). Therefore, the use of experimental design has important advantages over the more commonly used survey research 
in demonstrating how procedural justice affects the self-reported attitudes and behavior of police officers which has important implications for policing practices.

In the results section which follows, we present comparative driver and police officer results relating to perceptions of why the RBT was conducted, whether the RBT would change behavior, perceptions of police performance generally and as it related to the specific RBT and perceptions of trust in police and willingness to cooperate. Different analytical methods were used depending on the nature of the questions and/or scales involved; these are described in the relevant sections.

\section{Results}

\section{Reasons for Conducting RBTs}

Participants were able to select one of six options when asked what they thought the main reason was that police conducted random breath tests. Only a small proportion of respondents (both police and drivers) indicated that they thought that RBTs were conducted to raise revenue from fines (3.3\% of drivers; $1.0 \%$ of police) or to give police something to do $(0.7 \%$ of drivers; $1.9 \%$ of police), so these options are not discussed further.

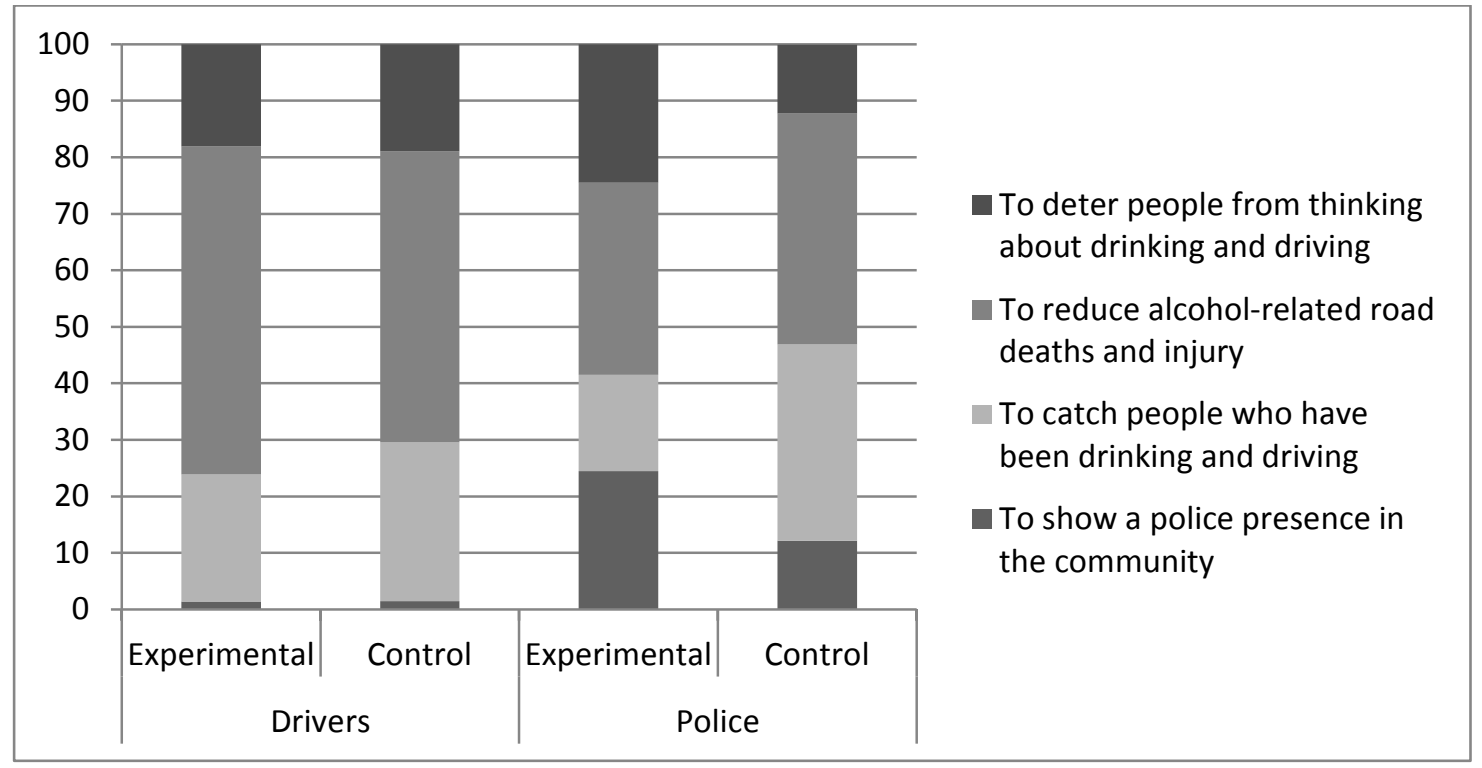

Figure 1. Reasons for Conducting RBTs by participant type and condition. 
As Figure 1 shows, most drivers in both conditions indicated that they believed the purpose of RBTs was to reduce alcohol-related deaths and injury (Experimental $=58.0 \%$; Control $=51.4 \%)$, followed by catching drink-drivers $($ Experimental $=22.5 \%$; Control $=$ 28.1\%), and deterring driving while intoxicated $($ Experimental $=18.1 \%$; Control $=24.5 \%)$. However, responses were more varied for police respondents across the two conditions. Although police in both conditions indicated reducing alcohol-related death and injury was the main reason for conducting RBTs (Experimental $=34.0 \%$; Control $=40.8 \%$ ), a larger proportion of police officers in the control condition believed RBTs were about catching drunk drivers - a detection rationale (34.7\% vs. $17.0 \%$ in Experimental). More officers in the experimental condition indicated deterrence and showing police presence (24.5\%, vs. $12.2 \%$ control - for both response options) were the reasons behind RBTs.

\section{Changing Behaviors}

Figure 2 shows the comparison of police officers' and drivers' views in each of the RBT conditions on whether the recent RBT will change drivers' views on a range of behaviors including drinking and driving, safe driving, speeding, vehicle maintenance and likelihood that the driver will become involved in a community group. Both drivers and police officers were able to respond to this question by answering yes or no.

Chi square analyses indicated that police officers, in both the control and experimental RBT conditions, were more likely to think the recent RBT had changed individuals’ driving while intoxicated behaviors (39.55\% indicated “yes”) than drivers themselves suggested (16.17\% indicated “yes”), $\chi_{\text {control }}^{2}(1)=36.30, p<.001, \varphi=.15, \chi_{\exp }^{2}$ (1) $=24.40, p<.001, \varphi=.15$. Similarly, in the experimental RBT condition, police officers were more likely to indicate that the RBT had had an impact on safe driving (34.00\% “yes”) than drivers (19.40\% “yes”), $\chi_{\exp }^{2}(1)=12.21, p<.001, \varphi=.10$. However, this effect was not 
seen in the control condition (drivers $14.6 \%$ “yes”; police $20.0 \%$ “yes”), $\chi^{2}$ control $(1)=1.536, p$ $=.286, \varphi=.03$.

There were no differences between police officers and drivers within the sample (in either condition) regarding the impact of the RBT on speeding, vehicle maintenance and the likelihood that the driver would become more involved in a community group or organization, $\chi^{2} s(1)<1.229$, ps $>.268, \varphi<.03$.

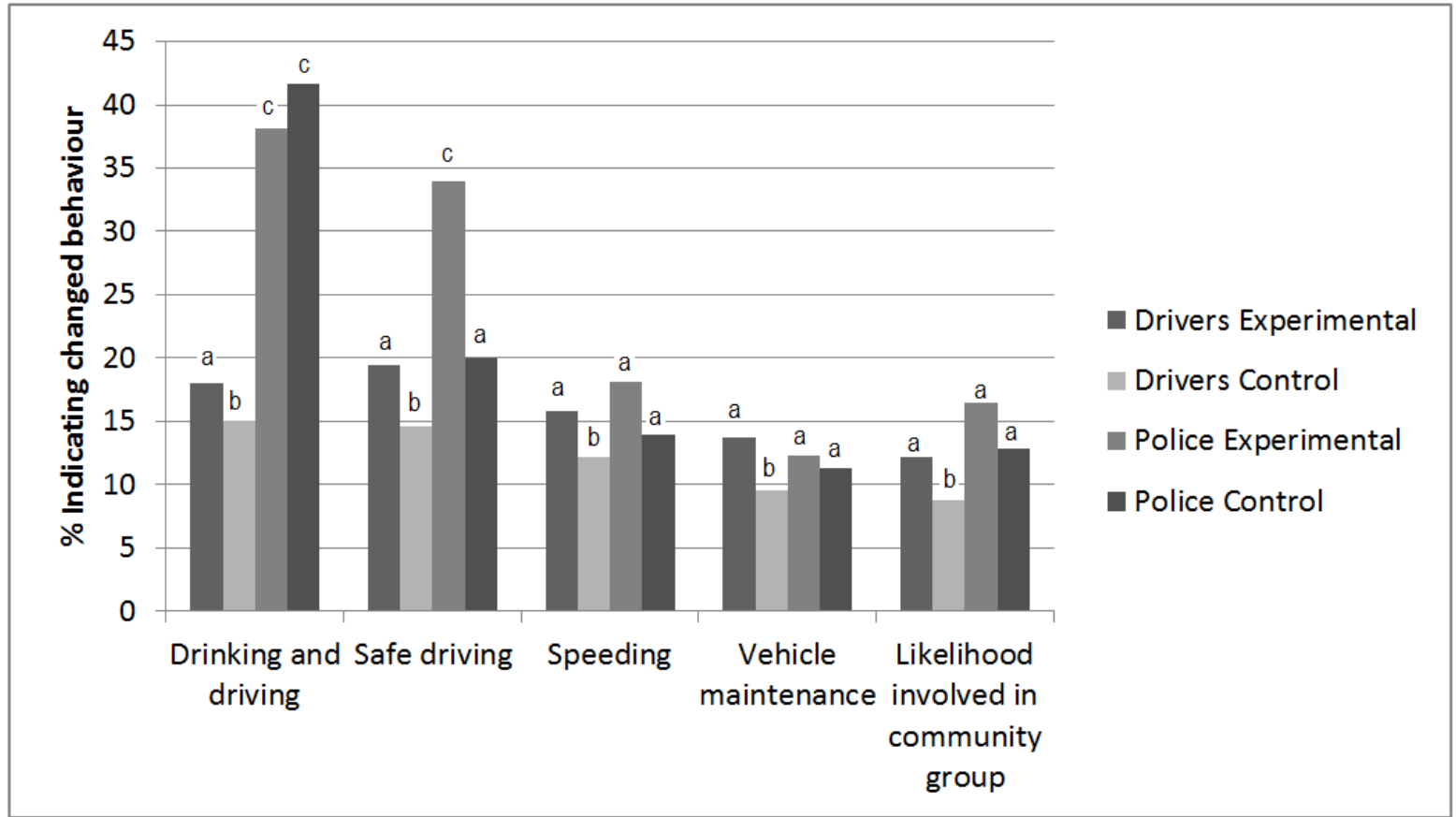

Note. Superscripts that differ indicate a significant difference in proportion responding affirmatively for item.

Figure 2. Changed views on behaviors following RBT by participant type and RBT condition.

Perceptions of Police Behavior during the RBT

A $2 \times 2$ between groups ANOVA ${ }^{12}$ was then conducted to investigate differences between police and drivers and RBT conditions in terms of their perceptions of the way the

${ }^{12}$ A 2x2 MANOVA was initially conducted to determine whether there were any effects of specific items. However, as the effects reported in the ANOVA were identical across the six items, the simpler univariate analysis of the scaled responses is presented. 
police acted in the RBT encounter. Results showed (see Figure 3) that police had overall higher ratings of their performance at the RBT $(M=4.56, S D=0.48)$ than did drivers $(M=$ 4.26, $S D=0.69), F(1,2914)=11.584, p<.001, \eta_{\mathrm{p}}{ }^{2}=.009$. Likewise, participants (both police and drivers) in the experimental condition had higher ratings of the police officers' performance $(M=4.41, S D=0.65)$ than those in the control condition $(M=4.19, S D=0.69)$, $F(1,2914)=3.718, p=.004, \eta_{\mathrm{p}}{ }^{2}=.003$. However, there was no interaction effect, $F(1,2914)$ $=1.776, p=.183, \eta_{\mathrm{p}}^{2}=.001$.

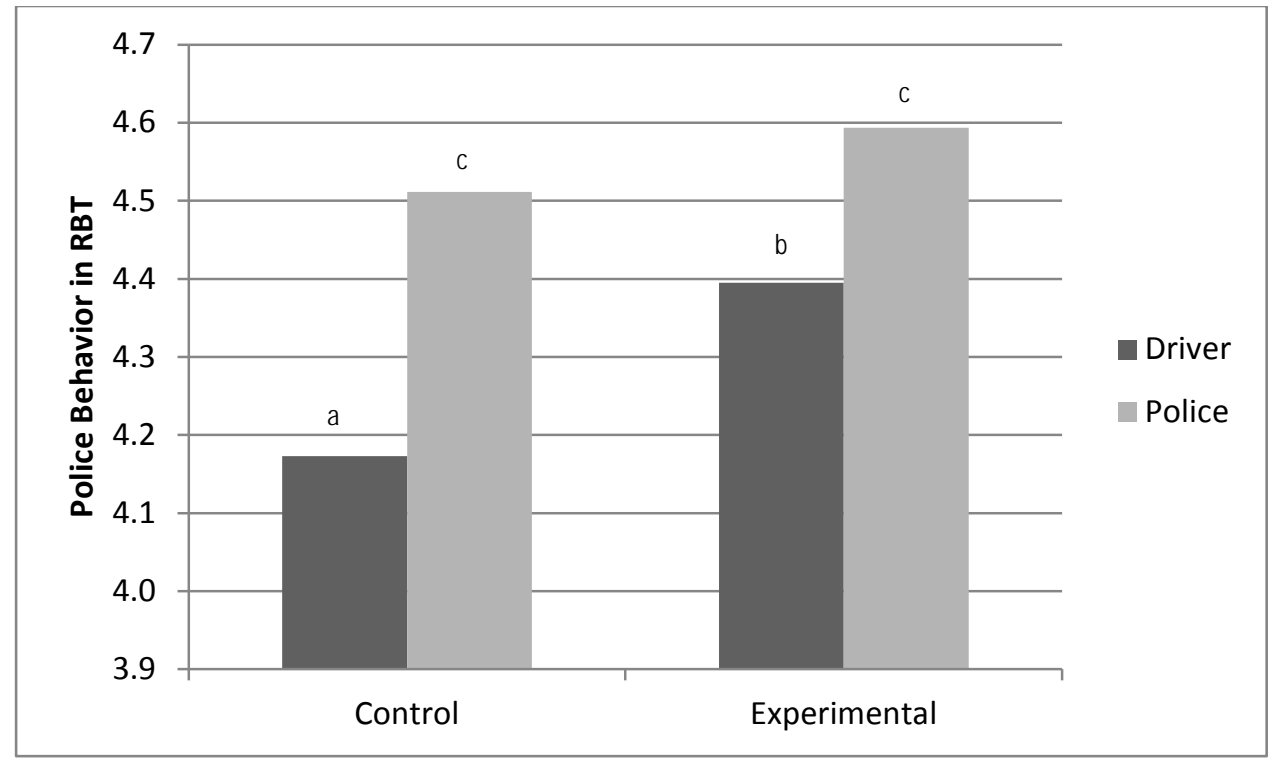

Note. Superscripts that differ indicate a significant difference between groups.

Figure 3. Perceptions of Police Behavior during the RBT by participant type and RBT condition.

\section{Perceptions of Police Performance - General}

Police and drivers were asked to reflect on how good a job they felt the police are doing overall in terms of solving crime, dealing with problems concerning citizens, working with the community, preventing crime, and keeping order. A MANOVA was conducted to examine the effects of both participant type and RBT condition, revealing a main effect of participant type, $F(5,2690)=5.273, p<.001, \eta^{2}=.01$, but no effect of condition or the 
interaction between condition and participant, $F s(5,2690)<1$, ps $>.643, \eta^{2}<.001$. Further exploration of the effect of participant type showed that differences between police and drivers could be seen in their views on the police solving crime $(F(1,2694)=16.747, p<.001$, $\left.\eta^{2}=.006\right)$, dealing with problems $\left(F(1,2694)=16.139, p<.001, \eta^{2}=.005\right)$, and working with the community $\left(F(1,2694)=5.096, p=.024, \eta^{2}=.002\right)$, such that police respondents thought that they were doing a better job at these things than did drivers (see Table 1). However, there were no differences between police and drivers in terms of their views on how good a job the police are doing on preventing crime and keeping order, $F s(1,2694)<3.023$, $p s>.082, \eta^{2} s$ $<.001$.

Table I. Mean Responses on Police Performance Items by Participant Type and Condition.

\begin{tabular}{|c|c|c|c|c|c|c|c|}
\hline & & \multicolumn{3}{|c|}{ Driver } & \multicolumn{3}{|c|}{ Police } \\
\hline & & Control & Experimental & $\begin{array}{l}\text { Driver } \\
\text { average }\end{array}$ & Control & Experimental & $\begin{array}{c}\text { Police } \\
\text { average }\end{array}$ \\
\hline \multirow[t]{2}{*}{ Solving crime } & $M$ & 3.56 & 3.58 & $3.57^{\mathrm{a}}$ & 3.86 & 3.9 & $3.88^{b}$ \\
\hline & $S D$ & 0.81 & 0.84 & 0.82 & 0.81 & 0.89 & 0.85 \\
\hline \multirow{2}{*}{$\begin{array}{l}\text { Dealing with } \\
\text { problems } \\
\text { that concern you }\end{array}$} & $M$ & 3.51 & 3.55 & $3.52^{\mathrm{a}}$ & 3.77 & 3.85 & $3.81^{\mathrm{b}}$ \\
\hline & $S D$ & 0.86 & 0.87 & 0.86 & 0.85 & 0.75 & 0.79 \\
\hline \multirow{2}{*}{$\begin{array}{l}\text { Working with } \\
\text { your community } \\
\text { to solve local } \\
\text { problems }\end{array}$} & M & 3.52 & 3.58 & $3.54^{\mathrm{a}}$ & 3.68 & 3.75 & $3.72^{\mathrm{b}}$ \\
\hline & $S D$ & 0.86 & 0.85 & 0.86 & 0.85 & 0.75 & 0.79 \\
\hline \multirow[t]{2}{*}{ Preventing crime } & M & 3.42 & 3.49 & $3.45^{\mathrm{a}}$ & 3.63 & 3.55 & $3.59^{\mathrm{a}}$ \\
\hline & $S D$ & 0.89 & 0.92 & 0.9 & 0.92 & 1.12 & 1.03 \\
\hline \multirow[t]{2}{*}{ Keeping order } & $M$ & 3.68 & 3.71 & $3.69^{a}$ & 3.79 & 3.84 & $3.82^{\mathrm{a}}$ \\
\hline & $S D$ & 0.83 & 0.86 & 0.84 & 0.8 & 1.09 & 0.96 \\
\hline
\end{tabular}

Note. ${ }^{2, b}$ Superscripts that differ indicate a significant difference between drivers and police on this item.

\section{Procedurally Just Behaviors}

A $2 \times 2$ between groups ANOVA $^{13}$ was then conducted to investigate differences between police and drivers and RBT conditions in terms of their perceptions of trust norms surrounding the actions of police. Results showed (see Figure 4) that police had overall lower ratings of the importance of these features $(M=4.49, S D=0.48)$ than did drivers $(M=4.76$,

${ }^{13}$ A 2x2 MANOVA was initially conducted to determine whether there were any effects of specific items. However, as the effects reported in the ANOVA were identical across the six items, the simpler univariate analysis of the scaled responses is presented. 
$S D=0.35), F(1,2868)=69.739, p<.001, \eta_{\mathrm{p}}{ }^{2}=.024$. However, there were no effects of the RBT condition, and no interactive effect of RBT condition and participant type, Fs $(1,2868)<$ $1, p s>.887, \eta_{\mathrm{p}}^{2} \mathrm{~s}<.001$

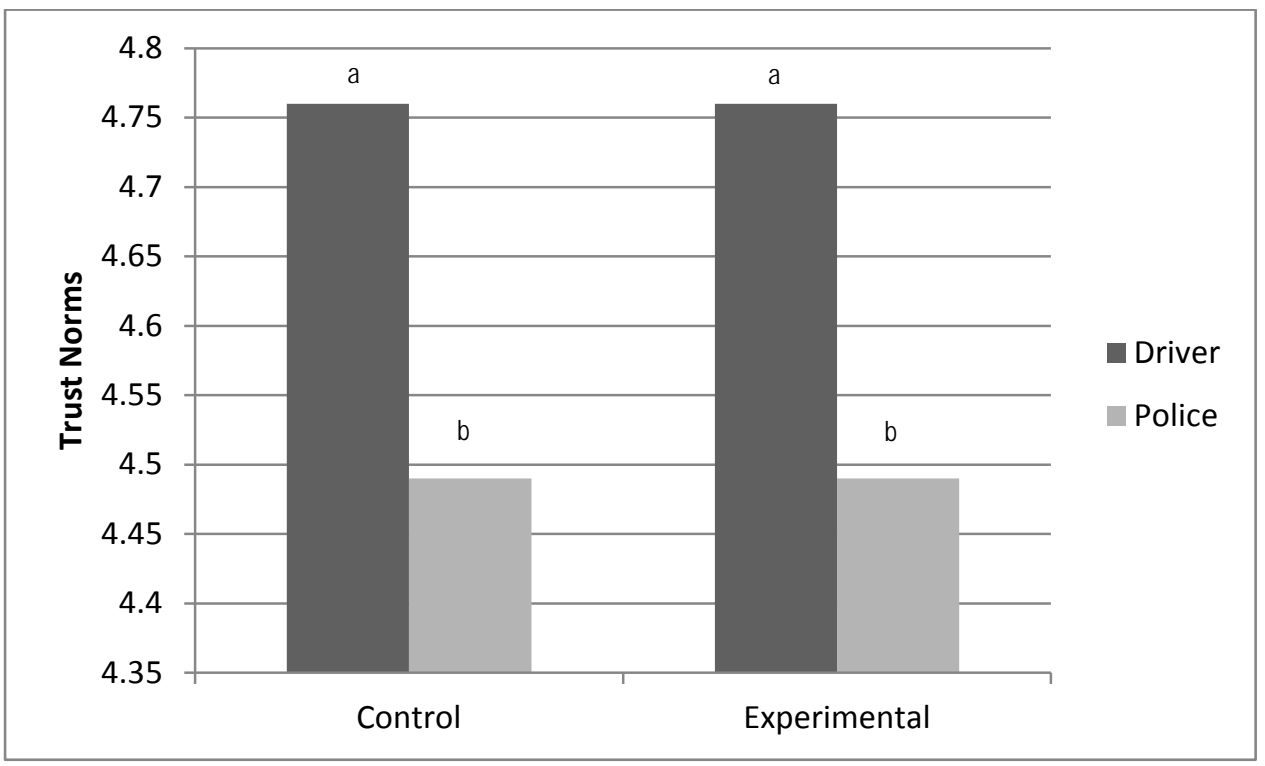

Note. Superscripts that differ indicate a significant difference between groups.

Figure 4. Trust norms surrounding police activities by participant type and RBT condition.

\section{Willingness to cooperate}

A $2 \times 2$ between groups ANOVA $^{14}$ was then conducted to investigate differences between police and drivers and RBT conditions in terms of their willingness (or perceptions of the public’s willingness) to cooperate with police. As with trust norms, results showed (see Figure 5) that police had overall lower ratings of the citizen's willingness to cooperate $(M=$ $3.91, S D=0.55)$ than did drivers $(M=4.50, S D=0.64), F(1,2846)=41.735, p<.001, \eta_{\mathrm{p}}{ }^{2}=$ .035. However, there were no effects RBT condition, and no interactive effect of RBT condition and participant type, Fs $(1,2846)<1.858$, ps $>.173, \eta_{\mathrm{p}}{ }^{2} \mathrm{~s}<.001$.

${ }^{14}$ A 2x2 MANOVA was initially conducted to determine whether there were any effects of specific items. However, as the effects reported in the ANOVA were identical across the six items, the simpler univariate analysis of the scaled responses is presented. 


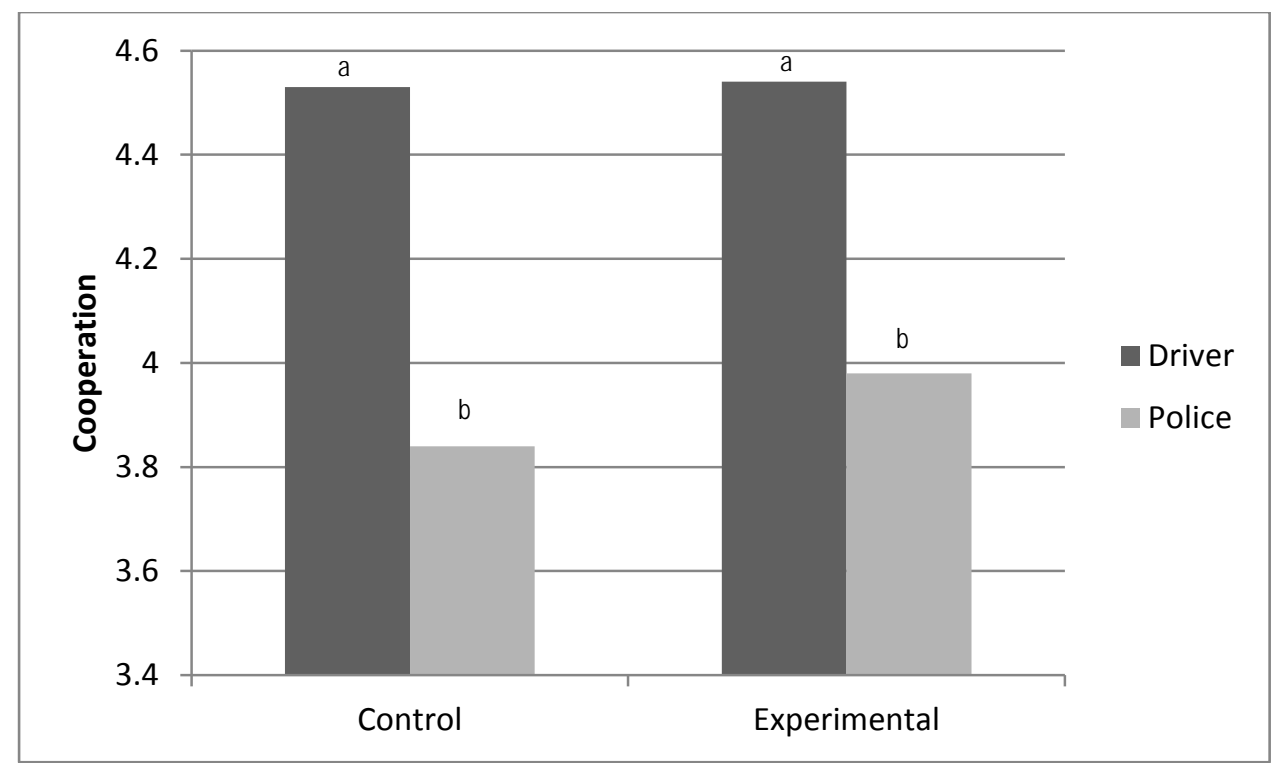

Note. Superscripts that differ indicate a significant difference between groups.

Figure 5. Cooperation by participant type and RBT condition.

\section{Discussion}

Despite the significant amount of research that has occurred within the area of procedural justice (e.g. Huq, Tyler, \& Schulhofer, 2011; J. Jackson et al., 2012; Murphy \& Barkworth, 2014), no studies have considered the views of police officers regarding interactions that incorporate the principles of procedural justice. This paper addresses this gap in the literature by exploring the differences and similarities between police and public perceptions of a routine encounter that incorporates the principles of procedural justice. Additionally, most of the prior work in this area (with some important exceptions, see for example Jonathan-Zamir et al., in press; Mastrofski, Snipes, \& Supina, 1996) has used correlational or survey based research to investigate the relationship between procedural justice and various outcomes such as trust or confidence in police as well as perceptions of police legitimacy. In contrast, QCET was the first randomized field trial that examined procedural justice.

The encounter used within QCET is an RBT which is a very common and standardized high volume interaction between police and drivers within Australia (Ferris et al., 2013). Police are able to stop any driver at any time in order to administer a breath test to assess if 
the driver is under the influence of alcohol (Voas \& Fell, 2013) and often RBTs are run in operations of several officers on a busy area of road to bring police into direct contact with a large proportion of individuals within a short time frame. The vast majority of the drivers that interact with police have not committed a driving under the influence offence. In its traditional form, there is limited use of the principles of procedural justice within the interaction.

However, our study found that the delivery of a RBT using a procedurally just script altered police officer views of the process. Police officers' views of the reason for the RBT encounter varied across conditions, with officers who delivered the procedurally just script being more likely to suggest that these types of encounters are about showing a police presence in the community, and officers in the business-as-usual condition being more likely to indicate these encounters are about “catching crooks”, or detecting offenders. This is an important finding and demonstrates that there is dis-congruence among police officers regarding the deterrent potential of the RBT process as it is implemented in Australia. There are two types of deterrence that can be present within a RBT operation: general and specific. As outlined earlier, general deterrence is designed to reduce driving while intoxicated in the community at large by showing a strong presence in the community (Bates et al., 2012). It appears that police officers who are participating in a procedurally just RBT interaction are more aware of the importance of demonstrating a police presence to reduce crashes due to intoxicated drivers in the broader community. In contrast, those police officers undertaking the traditional RBT were operating more in line with the principles of specific deterrence where the aim is to catch those who actually offend (Ferris et al., 2013).

Drivers views' about the reason for the encounter did not vary based on the experimental condition, and largely suggested drivers felt that the police had trustworthy motives regarding RBT encounters. Interestingly, almost no drivers reported that they thought these encounters 
were only about the police showing a presence in the community. This suggests that drivers believe the police are undertaking an important role when they are conducting RBT operations.

Our study indicated some differences regarding the perceptions of police and drivers regarding the RBT interaction. The police perceived that the RBT encounter has a stronger impact on the drivers' views than the drivers report. This was particularly the case when the RBT interaction incorporated the principles of procedural justice (experimental operations). Police officers were more likely to report that they were having a bigger influence on drivers' behaviors than the drivers indicated that they thought the police officers were doing. This finding has important implications for perceptions of police effectiveness. Specifically, that police could gain a more comprehensive and realistic picture of how their organization is performing if they take into account the perceptions of external stakeholders in relation to specific encounters or police enforcement activities.

Results highlighted that during the RBT encounter, the police officers perceived that procedurally just behaviors were less important than the drivers themselves reported. Given that there is now strong evidence that interactions with citizens which incorporate procedural justice can promote a range of benefits including greater perceived legitimacy of the police organization and higher levels of compliance with police (Murphy et al., 2008; Sunshine \& Tyler, 2003), there may be a need for police to translate the importance and the method of incorporating procedural justice dialogue into even short ‘benign’ encounters with citizens. Police officers should be encouraged to use these principles in all interactions with citizens given the level of importance that citizens attach to this process.

Finally, the police believed that the public were less willing to cooperate with them when compared with the drivers in this study. This finding is somewhat encouraging as it indicates that many citizens are more willing to cooperate with police than the police believe. This is 
particularly important when all drivers can be pulled over at any time by police in order to undertake a compulsory breath test, as in the case in Queensland and other jurisdictions that operate a RBT model. However, it also points to a discrepancy between police and drivers' perception of the interaction which may, in other circumstances, lead to misunderstandings between the police and the public. For instance, if a citizen believes themselves to be fully compliant and cooperative while the police officer perceives this citizen to be non-compliant, this misunderstanding could lead to police asserting compliance unnecessarily.

\section{Limitations}

This study provides some important insights into some of the differences that occur in police officer and driver perceptions of the same interaction. However, within our study, there are a few factors that limit our findings. Due to the de-identified nature of the driver and police surveys, it was not possible to explicitly link drivers and police officers perceptions of the same interaction. It would be interesting to undertake a study that was able to directly compare police and citizen perceptions of the same procedurally just interaction rather than make comparisons at a more global level.

Additionally, there were a smaller number of police officers who completed the survey when compared with drivers. Some of the police officers, if they had been involved in more than one of the trial RBT operations, completed more than one survey. Researchers attempted to control for this potential confound by asking police officers to complete the whole survey the first time they participated in a RBT operation which was part of the experiment and subsequently to only complete designated parts of the survey when they participated in additional QCET RBTs.

Although police officers interact with citizens in a range of ways, the QCET experiment was focused on one particular interaction - the RBT. This focus provided a more controlled 
interaction for use within the experiment. However, it may limit the findings of the experiment to the other types of interactions that police and citizens engage in. Despite this, the current study adds to the growing body of research indicating the importance of procedural justice in police citizen interactions in countries including Australia (e.g. Murphy et al., 2008), the United Kingdom (e.g. Myhill \& Bradford, 2011) and the United States of America (e.g. Tyler, Schulhofer, \& Huq, 2010). Future research should consider comparing police and citizen perceptions of a procedurally just interaction in other contexts including other road policing situations (e.g. Bates, 2014). Additionally, all of the research in the field of procedural justice and policing is focused on face-to-face interactions with police. Further research should explore whether the principles of procedural justice can be applied to, and the effects of such application, to police-citizen interactions that occur in other contexts that are not face-to-face.

\section{Implications and Future Directions}

Our study provides an important addition to the existing procedural justice literature as it clearly demonstrates that a procedurally just interaction affects both police officers and citizens. This finding has important implications for both policing practices and further research.

The findings of our study have important implications for police activities. Although the findings of this study are focused on an RBT interaction as the context, the findings should generalize across other policing jurisdictions and activities where police officers are undertaking a large volume of routine encounters with citizens such as other types of traffic stops or common face-to-face interactions with police. Further research would confirm this.

The difference in perceptions between police officers and citizens is an interesting finding. Police officers perceive that their work has a stronger effect on citizens than the 
citizens’ report. This suggests that police should consider using external monitoring mechanisms to gain a more rounded appreciation of the impact of their work. Further, it may suggest that police underestimate the value that the general community place on the work the police do. That is, the small number of citizens indicating their views changed on some issues may simply be a reflection of the fact that citizens already held quite positive and pro-social views on these matters. For police to believe that they are more often changing citizens' views on these issues may be an indication that they perceive citizens to have less pro-social views than they truly do. In some situations, this discrepancy may have the potential to damage citizens’ views of police.

Additionally, the results demonstrate that the use of a procedurally just interaction affects police officer perceptions as well as citizen perceptions. It is interesting, for example, that police officers have different perceptions of the deterrent potential of RBT operations depending on whether they were delivering the standard RBT or the procedurally just RBT. It appears that when officers are trained to use procedural justice during routine encounters, they are less likely to see these encounters as solely for the purpose of 'catching offenders' but rather as a way of having a greater presence in the community. Procedural justice training can be easily operationalized to a wide range of routine police activities with broad reaching benefits to police and citizens.

The difference in perceptions between police officers and citizens suggests that there is a need to understand how police officers perceive their own legitimacy and the impact that interactions with citizens has on these perceptions. As noted by Bottoms and Tankebe (2012), it is possible for police officers and citizens to have different perceptions of legitimacy with wide reaching implications for criminal justice agencies. Additionally, research undertaken with Israeli police suggests that police officers and citizens differ in what they associate with legitimacy. Police were more likely to associate performance while citizens were more likely 
to associate procedural justice (Jonathan-Zamir \& Harpaz, 2014). The results of our study suggest that it is possible, by altering the dynamics of an interaction between citizens and police, to change police officers perceptions. While further research is required, this finding suggests that police citizen interactions may be an opportunity to not only teach citizens about legitimacy but also provide a key opportunity to do so with police officers. 


\section{References}

Adams, R., Rohe, W., \& Arcury, T. (2005). Awareness of community-oriented policing and neighborhood perceptions in five small to midsize cities. Journal of Criminal Justice, 33(1), 43-54. doi: dx.doi.org/10.1016/j.jcrimjus.2004.10.008

Ajzen, I., \& Fishbein, M. (1977). Attitude-behavior relations: A theoretical analysis and review of empirical research. Psychological Bulletin, 84(5), 888-918. doi: 10.1037/0033-2909.84.5.888

Allen, J., Edmonds, S., Patterson, A., \& Smith, D. (2006). Policing and the criminal justice system - public confidence and perceptions: findings from the 2004/05 British Crime Survey. London: Home Office.

Antrobus, E., Elffers, H., White, G., \& Mazerolle, L. (2013). Nonresponse Bias in Randomized Control Experiments in Criminology: Putting the Queensland Community Engagement Trial (QCET) Under a Microscope. Evaluation Review, 37, 197-212. doi: 10.1177/0193841X13518534

Aviv, G. (2014). Crime victims and attitudes towards the police: The Israeli case. Police Practice and Research: An International Journal, 15(2), 115-129. doi: $10.1080 / 15614263.2013 .874170$

Bates, L. (2014). Procedural justice and road policing: Is it important? Paper presented at the Road Safety Research, Policing and Education Conference, Melbourne, Australia.

Bates, L., Soole, D., \& Watson, B. (2012). The effectiveness of traffic policing in reducing traffic crashes. In T. Prenzler (Ed.), Policing and Security in Practice: Challenges and Achievements: Palgrave Macmillan.

Bottoms, A., \& Tankebe, J. (2012). Beyond procedural justice: A dialogic approach to legitimacy in criminal justice. The Journal of Criminal Law and Criminology, 102(1), 119-170. 
Brandl, S., Frank, J., Worden, R., \& Bynum, T. (1994). Global and specific attitudes toward the police: Disentangling the relationship. Justice Quarterly, 11(1), 119-134. doi: $10.1080 / 07418829400092161$

Bridenball, B., \& Jesilow, P. (2008). What matters: The formation of attitudes towards police. Police Quarterly, 11(2), 151-181.

Brown, B., \& Benedict, W. (2002). Perceptions of the police: Past findings, methodological issues, conceptual issues and policy implications. Policing: An International Journal of Police Startegies and Management, 25(3), 543-580.

Chermak, S., McGarrell, E., \& Gruenewald, J. (2006). Media coverage of police misconduct and attitudes toward police. Policing: An International Journal of Police Strategies and Management, 29(2), 261-281. doi: 10.1108/13639510610667664

Cheurprakobkit, S. (2000). Police-citizen contact and police performance: Attitudinal differences between Hispanics and non-Hispanics. Journal of Criminal Justice, 28(4), 325-336.

Chow, H. (2010). Police-public relations: perceptions of the police among university students in a western Canadian city. International Journal of Criminology and Sociological Theory, 3(2), 496-511.

Chow, H. (2011). Adolescent attitudes toward the police in a western Canadian city. Policing: An International Journal of Police Strategies and Management, 34(4), 638653.

Cordner, G., \& Jones, M. (1995). The effects of supplementary foot patrol on fear of crime and attitudes toward police. In P. Kratcoski \& D. Dukes (Eds.), Issues in Community Policing (pp. 180-1498). Highland Heights: Anderson Publishing Co.

Davey, J., \& Freeman, J. (2011). Improving road safety through deterrence-based initiatives: A review of research. Sultan Qaboos University Medical Journal, 11(1), 29-37. 
Farrington, D. (2003). A short history of randomized experiments in criminology: A meager feast. Evaluation Review, 27(3), 218-227. doi: 10.1177/0193841X03252482

Farrington, D., \& Welsh, B. (2005). Randomized experiments in criminology: What have we learned in the last two decades? Journal of Experimental Criminology, 1, 9-38.

Ferris, J., Mazerolle, L., King, M., Bates, L., Bennett, S., \& Devaney, M. (2013). Random Breath Testing in Queensland and Western Australia: What is the Optimum Ratio of Breath Testing to Licensed Drivers? Accident Analysis and Prevention, 60, 181-188.

Frank, J., Smith, B., \& Novak, K. (2005). Exploring the Basis of Citizens' Attitudes Toward the Police. Police Quarterly, 8(2), 206-228. doi: 10.1177/1098611103258955

Freeman, J., \& Watson, B. (2006). An application of Stafford and Warr's reconceptualisation of deterrence to a group of recidivist drink drivers. Accident Analysis \& Prevention, 38, $462-471$.

Gau, J. (2010). A longitudinal analysis of citizens' attitudes about police. Policing: An International Journal of Police Strategies and Management, 33(2), 236-252.

Gau, J., Corsaro, N., Stewart, E., \& Brunson, R. (2012). Examining macro-level impacts on procedural justice and police legitmacy. Journal of Criminal Justice, 40, 333-343.

Goodman-Delahunty, J. (2010). Four ingredients: new recipes for procedural justice in Australian policing. Policing, 4(4), 403-410.

Hart, S., Watson, B., \& Tay, R. (2003). Barriers and facilitators to the effective operation of RBT in Queensland. Paper presented at the 2003 Road Safety Research, Policing and Education Conference: From Research to Action, Sydney.

Hinds, L., \& Murphy, K. (2007). Public satisfaction with police: Using procedural justice to improve police legitimacy. The Australian and New Zealand Journal of Criminology, 40(1), 27-42. 
Homel, R. (1989). Crime on the roads: Drinking and driving. Paper presented at the Alcohol and Crime Conference.

Homel, R. (1993). Random breath testing in Australia: Getting it to work according to specifications. Addiction, 88(Supplement), 27S-33S.

Hoover, L. T., Dowling, J. L., \& Fenske, J. W. (1998). Extent of Citizen Contact With Police. Police Quarterly, 1(3), 1-18. doi: 10.1177/109861119800100302

Huq, A., Tyler, T., \& Schulhofer, S. (2011). Why does the public cooperate with law enforcement? Psychology, Public Policy and Law, 17(3), 419-450. doi: 10.1037/a0023367

Ioimo, R., Becton, J., Meadows, L., Tears, R., \& Charles, M. (2009). Comparing the police and citizen views on biased policing. Criminal Justice Studies: A Critical Journal of Crime, Law and Society, 22(2), 123-140.

Jackson, A., \& Wade, J. (2005). Police perceptions of social capital and sense of responsibility: An explanation of proactive policing. Policing: An International Journal of Police Strategies and Management, 28(1), 49-68.

Jackson, J., Bradford, B., Hough, M., Myhill, A., Quinton, P., \& Tyler, T. (2012). Why do people comply with the law? Legitimacy and the Influence of Legal Institutions. British Journal of Criminology, 52, 1051-1071. doi: 10.1093/bjc/azs032

Jackson, J., Bradford, B., Kuha, J., \& Hough, M. (in press). Empirical legitimacy as two connected psychological states. In G. Mesko \& J. Tankebe (Eds.), Improving Legitimacy of Criminal Justice in Emerging Democracies. London, United Kingdom: Springer.

Jonathan-Zamir, T., \& Harpaz, A. (2014). Police understanding of the foundations of their legitimacy in the eyes of the public: The case of commanding officers in the Israel 
National Police. British Journal of Criminology, 54(3), 469-489. doi: 10.1093/bjc/azu001

Jonathan-Zamir, T., Mastrofski, S., \& Moyal, S. (in press). Measuring procedural justice in police-citizen encounters. Justice Quarterly. doi: 10.1080/07418825.2013.845677

Kennedy, D., \& Homant, R. (1985). Police perceptions of spouse abuse: A comparison of male and female officers. Journal of Criminal Justice, 13(1), 29-47.

Lai, Y., \& Zhao, J. (2010). The impact of race/ethnicity, neighborhood context, and police/citizen interaction on residents' attitudes toward the police. Journal of Criminal Justice, 38(4), 685-692. doi: 10.1016/j.jcrimjus.2010.04.042

Liederbach, J., Fritsch, E., Carter, D. L., \& Bannister, A. (2008). Exploring the limits of collaboration in community policing: A direct comparison of police and citizen views. Policing: An International Journal of Police Strategies \& Management, 31(2), 271291. doi: $10.1108 / 13639510810878721$

Lind, E., \& Tyler, T. (1988). The social psychology of procedural justice. New York: Plenum.

Lopez, N., \& Lukinbeal, C. (2010). Comparing police and residents' perceptions of crime in a Phoenix neighborhood using mental maps in GIS. Yearbook of the Association of Pacific Coast Geographers, 72, 33-55. doi: 10.1353/pcg.2010.0013

Mastrofski, S., Snipes, J., \& Supina, A. (1996). Compliance on demand: The public's response to sepcific police requests. Journal of Research in Crime and Delinquency, 33(3), 269-305.

Mazerolle, L., Bates, L., Bennett, S., Ferris, J., White, G., \& Antrobus, E. (in press). Optimising the length of random breath tests: Results from the Queensland Community Engagement Trial. Australian \& New Zealand Journal of Criminology. 
Mazerolle, L., Bennett, S., Antrobus, E., \& Eggins, E. (2012). Procedural Justice, Routine Encounters and Citizen Perceptions of Police: Main Findings from the Queensland Community Engagement Trial (QCET). Journal of Experimental Criminology, 8, 343-367.

Mazerolle, L., Bennett, S., Antrobus, E., \& Tyler, T. (2013). Shaping citizen perceptions of police legitimacy: A randomized field trial of procedural justice. Criminology, 51(1), 33-63. doi: 10.1111/j.1745-9125.2012.00289.x

Moore, M. H. (1992). Crime and justice - A review of research: Problem solving and community policing. In M. Tonry \& N. Norris (Eds.), Modern Policing (Vol. 15, pp. 99-158). Chicago: Chicago University Press.

Morabito, M. (2010). Understanding community policing as an innovation: Patterns of adoption. Crime \& Delinquency, 56(4), 564-587. doi: 10.1177/0011128707311643

Murphy, K. (2009). Procedural justice and affect intensity: Understanding reactions to regulatory authorities. Social Justice Research, 22(1), 1-30. doi: 10.1007/s11211-0080086-8

Murphy, K., \& Barkworth, J. (2014). Victim willingness to report crime to police: Does procedural justice or outcome matter most? Victims \& Offenders: An International Journal of Evidence-based Research, Policy and Practice, 9(2), 178-204. doi: $10.1080 / 15564886.2013 .872744$

Murphy, K., Hinds, L., \& Fleming, J. (2008). Encouraging public cooperation and support for police. Policing and Society, 18(2), 136-155.

Murphy, K., Mazerolle, L., \& Bennett, S. (2014). Promoting trust in police: findings from a randomised experimental field trial of procedural justice policing. Policing and Society: An international Journal of Research and Policy, 24(4), 405-424. doi: 10.1080/10439463.2013.862246 
Murphy, K., Murphy, B., \& Mearns, M. (2010). The 2007 public safety and security in Australia survey: survey methodology and preliminary findings. Australia: Deakin University.

Myhill, A., \& Bradford, B. (2011). Can police enhance public confidence by improving quality of service? Results from two surveys in England and Wales. Policing and Society: An international Journal of Research and Policy, 1-29.

Myrstol, B. (2012). The alcohol-related workload of patrol officers. Policing: An International Journal of Police Strategies and Management, 35(1), 55-75.

Nagin, D. (2013). Deterrence in the twenty-first century. Crime and Justice, 42(1), 199-263.

O'Connor, C. (2008). Citizen attitudes toward the police in Canada. Policing: An International Journal of Police Strategies and Management, 21(4), 578-595. doi: $10.1108 / 13639510810910571$

Oliveira, A., \& Murphy, K. (in press). Race, Social Identity, and Perceptions of Police Bias. Race and Justice.

Palk, G., Davey, J., \& Freeman, J. (2007a). Policing alcohol-related incidents: A study of time and prevalence. Policing: An International Journal of Police Strategies and Management, 30(1), 82-92.

Palk, G., Davey, J., \& Freeman, J. (2007b). Prevalence and characteristics of alcohol-related incidents requiring police attendance. Journal of Studies on Alcohol and Drugs, 68(4), 575-581.

Peek-Asa, C. (1999). The effect of random alcohol screening in reducing motor vehicle crash injuries. American Journal of Preventative Medicine, 16(1, Suppliment 1), 57-67.

Reisig, M., \& Correia, M. (1997). Public evaluations of police performance: An analysis across three levels of policing. Policing: An International Journal of Police Strategies and Management, 20(2), 311-325. doi: 10.1108/13639519710169153 
Roberts, L., \& Indermaur, D. (2009). What Australians think about crime and justice: Results from the 2007 Australian survey of social attitudes Australian Institute of Criminology Research and Public Police Series (Vol. 101). Canberra: Australian Institute of Criminology.

Sargeant, E., Antrobus, E., Murphy, K., Bennett, S., \& Mazerolle, L. (in press). Social identity and procedural justice in police encounters with the public: results from a randomised controlled trial. Policing and Society: An International Journal of Research and Policy. doi: 10.1080/10439463.2014.989159

Sargeant, E., \& Bond, C. (in press). Keeping it in the family: Parental influences on young people’s attitudes to police. Journal of Sociology. doi: 10.1177/1440783313482817

Sargeant, E., Murphy, K., Davis, J., \& Mazerolle, L. (2012). Legitimacy and Policing. In T. Prenzler (Ed.), Policing and Security in Practice: Challenges and Achievements. United Kingdom: Palgrave Macmillan.

Skogan, W. G. (1990). The Police And Public In England And Wales: A British Crime Survey Report. London: Home Office.

Sunshine, J., \& Tyler, T. (2003). The role of procedural justice and legitimacy in shaping public support for policing. Law and Society Review, 37(3), 513-547.

Tankebe, J. (2009). Public cooperation with the police in Ghana: Does procedural fairness matter? Criminology, 47(4), 1265-1293. doi: 10.1111/j.1745-9125.2009.00175.x

Tyler, T. (2003). Procedural justice, legitimacy, and the effective rule of law. In M. Tonry (Ed.), Crime and Justice: A Review of Research (Vol. 30). Chicago: University of Chicago Press.

Tyler, T. (2004). Enhancing police legitimacy. The Annals of the American Academy of Political and Social Science, 593, 84-99. 
Tyler, T., \& Fagan, J. (2008). Legitimacy and cooperation: Why do people help the police fight crime in their communities? Ohio State Journal of Criminal Law, 6, 231-275.

Tyler, T., \& Huo, Y. (2002). Trust in the law. New York: Russell-Sage.

Tyler, T., Schulhofer, S., \& Huq, A. (2010). Legitimacy and Deterrence Effects in Counterterrorism Policing: A Study of Muslim Americans. Law \& Society Review, 44(2), 365-401.

Tyler, T., \& Wakslak, C. (2004). Profiling and police legitimacy: Procedural justice, attributions of motive and acceptance of police authority. Criminology, 42(2), 253281.

van der Toorn, J., Tyler, T., \& Jost, J. (2011). More than fair: Outcome dependence, system justification, and the perceived legitimacy of authority figures. Journal of Experimental Social Psychology, 47, 127-138. doi: 10.1016/j.jesp.2010.09.003

Voas, R., \& Fell, J. (2013). Strengthening impaired-driving enforcement in the United States. Traffic Injury Prevention, 14(7), 661-670. doi: 10.1080/15389588.2012.754095

Vogel, B. (2011). Perceptions of the police: The Influence of individual and contextual factors in a racially diverse urban sample. Journal of Ethnicity in Criminal Justice, 9(4), 267-290. doi: 10.1080/15377938.2011.609399

Waddington, P., Williams, K., Wright, M., \& Newburn, T. (2015). Dissension in public evaluations of the police. Policing and Society: An International Journal of Research and Policy, 25(2), 212-235. doi: 10.1080/10439463.2013.833799

Watson, B., \& Freeman, J. (2007). Perceptions and Experiences of Random Breath Testing in Queensland and the Self-Reported Deterrent Impact on Drunk Driving. Traffic Injury Prevention, 8(1), 11-19. 
Wells, W. M., \& Schafer, J. A. (2006). Officer perceptions of police responses to persons with a mental illness. Policing: An International Journal of Police Strategies and Management, 29(4), 578-601.

Wu, Y., Sun, I., \& Triplett, R. (2009). Race, class or neighborhood context: Which matters more in measuring satisfaction with Police? Justice Quarterly, 26(1). doi: $10.1080 / 07418820802119950$ 